\title{
ラットの時間弁別行動における 中枢アセチルコリン（神経）系の役割について
}

\author{
日本学術振興会（同志社大学） 畑 敏道 ${ }^{2}$
}

The role of the central cholinergic neuron systems in temporal discrimination in rats

\author{
TOSHIMICHI HATA \\ Research Fellow of the Japan Society for the Promotion of Science, Department of Psychology, \\ Doshisha University, Karasuma Imadegawa, Kamigyo-ku, Kyoto 602-8580
}

\begin{abstract}
In this paper, we review the studies which aim to understand the effects of the central cholinergic manipulation on the temporal discrimination behavior. We start with a brief introduction of the tasks and their properties used in the studies of temporal discrimination. After that, we summarize the features of the studies in which the cognitive process theories are not considered. Then we sketch a representative cognitive model, "the information processing model," and summarize the features of the studies which were executed on the basis of this model. We clarify some distinctions between these two types of studies and point out the two variables which may cause those distinctions: the number of trainings under drug treatment and the potency of the drug. Next, we present our experiment in which the effects of these two variables on temporal discrimination were examined, and suggest some questions about the information processing model and the hypothesis of correspondence between the model and the cholinergic systems.
\end{abstract}

Key words : temporal discrimination, cholinergic, information processing model, rats.

\begin{abstract}
本稿では，ラットを中心として，中枢アセチルコ リン (神経) 系 (以下ACh系) の操作が時間弁別行 動に与える効果を検討した研究を概観する。はじめ に, 時間弁別行動の研究で用いられてきた主な課題 とその特徴を簡単に説明する。次に, ACh系の操作 によって生じる行動の変化のみを興味の対象として いた研究を概観し，その結果と解釈の特徽を明らか にする。1980年代に入ると，時間弁別行動を潜在的 な要因（ここでは，認知的処理などの潜在的な過程 一般を意味する。以下, 媒介過程と記述する)によっ て説明するモデルが提出され，損傷や薬物投与など の効果をそれに基づいて解釈しようとする研究があ らわれてきた。その代表である “情報処理モデル (information processing model)”について簡単に
\end{abstract}

1 現所属：同志社大学文学研究科

2 別刷請求 e-mail : lq3502@mail2.doshisha.ac.jp
説明する。そして, ACh系の操作によって生じた行 動の変化を情報処理モデルによって解釈した研究を 概観し, ACh系と情報処理モデルとの対応について の仮説を紹介する。ところで，情報処理モデルに言 及した研究で得られた特徴的な結果は, 媒介過程を 想定していなかった研究の結果とは異なっていた。 そこで, その違いを明らかにした後, その違いを生 じさせた可能性のある要因として, 薬物投与下での 訓練回数と, 薬物が持つ中枢神経の活動や行動を変 化させる作用の強さの違いという 2 つの変数を指摘 する。そして, その $2 つ の$ 変数の相互作用について 検討した我々の研究を紹介し, 情報処理モデルおよ び情報処理モデルとACh系との対応についての仮説 の問題点を指摘する。最後に, ACh系が時間弁別行 動において果たす役割を解明するうえで今後行うべ き研究について展望する。 


\section{1．時間弁別研究に用いられてきた課題}

時間弁別行動の研究に用いられてきた課題には, 大別して強化スケジュールによるものと, 視聴覚刺 激の持続時間の弁別によるものとがある。本稿では, その両手続きで形成される行動を総称して時間弁別 行動之呼ぶ。以下に, 各課題の特徵と測度について 述べる。測度は, 時間弁別の感度の良さについての 測度を “時間弁別の指標”とし，主観的な時間の長 さについての測度を“時間評価の指標”と呼んで区 別することにする。

\section{1 強化スケジュールによる課題}

低反応率分化強化 (differential reinforcement of low rates；DR L) と定間隔強化 (fixed interval ; F I ）が代表的なスケジュールである。これらはご く基本的な強化スケジュールであるので，詳細につ いてはここでは述べない。DＲＬでは反応間間隔（I R T ）の度数分布の尖度が時間弁別の指標に, 最頻 值が時間評価の指標になる。このスケジュールは, 時間評価を測定するのに「きわめて厳密な手続き」(岩 本，1981）である一方で，反応抑制課題としての性 質が含まれていると考えられるため, 反応抑制を解 除する効果を持つ薬物を投与する場合には必ずしも 測時課題として適切であるとは限らないかもしれな い(舌間・岩崎, 1990)。F I では, スキャロップパ ターンが時間弁別の指標となる。スキャロップの程 度は, curvature index (C I ) によって数量化が可 能である (Fry, Kelleher, \& Cook, 1960)。C I は一 1 から 1 の範囲を取り, 正の值が大きいほど要求時 間に向かっての反応率の上昇の程度が大きいことを, 負の值が大きいほど反応率の下降の程度が大きいこ とを，０は反応率が変化しないことを示す。

ピークインターバル手続き (peak interval procedure；P I ）は, Catania (1970) が考案し, Roberts (1981) 以降に広く用いられるようになった 課題である。この手続きは離散試行型のF I スケジュー ルの変形版であり, 2 つのタイフの試行で構成され ている。強化試行 (food trial) では, 通常の離散試 行のF I スケジュールと同様に，光や音などの信号 刺激の呈示開始から要求時間が経過した後の最初の 反応が強化され，それと同時に信号刺激が停止し， 試行間間隔に移行する。無強化試行 (empty trial) では, 強化試行と同様に試行が開始されるが, 要求 時間を過ぎても一定時間試行が継続する。無強化試 行は多くの場合, 強化試行の数倍程度の時間で持続 し, 反忘とは無関係に終了する。この試行中に生じ た反応には強化を一切与えない。無強化試行での反 応数を, 試行開始からの経過時間の関数として分布
させると, 要求時間付近に最大反応率をもつ逆U字 型の反応率分布が得られる。この分布での最大の反 応率をピークレイト，その時間をピークタイムと呼 ぶ。この反応率分布の尖度が時間弁別の指標になる。 反応率分布の尖度は，ピークレイトを試行中のすべ ての反応率の平均で割った值(discrimination index; D I ) として数量化することも可能である (Meck \& Church, 1987 a )。反応率分布の尖度が大きいほどこ の值も大きくなる。一方, ピークタイムは時間評価 の指標となる。この課題は, 後に述べる情報処理モ デルの発展に大きく貢献した。

\section{2 持続時間の弁別による課題}

間隔二等分課題（temporal bisection; Church, 1980 ; Church, Getty, \& Lerner, 1976) では, ある 持続時間を持つ光や音などの刺激が呈示される。刺 激呈示終了後, それが短い持続時間（例えば $2 \mathrm{~s}$ ) であれば一方のレバーに，長い持続時間（例えば 8 s）であれば他方のレバーに反応することが求めら れる。この訓練後, この長短 2 刺激に加えて, 両持 続時間の間で, 持続時間の異なる複数の刺激 $(2.6$,

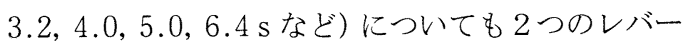
への反応を求める。そして, それぞれの刺激に対し て生じた各レバーへの反応率を算出する。一方のレ バーへの反応率が $25 \%$ になる刺激持続時間と $75 \%$ に なる刺激持続時間の差の 2 分の 1 を弁別閾 (D L ) とし，時間弁別の指標とする (Meck, 1983)。また, 両方のレバー一の反応率が等しくなる刺激の長さ (二 等分点； bisection point）を求め，それを時間評価 の指標とする。この課題では刺激提示後に 1 回反応 を行うだけなので, 薬物の投与による反応率の上昇 の影響を受けにくい。

\section{2. 媒介過程を想定していない研究}

以下に, 用いられた手続きごとに, 媒介過程を想 定していない研究を概観する。特に断らない限り, 薬物は単回性の腹腔内投与である。用いられた薬物 であるスコポラミンとアトロピンは, ムスカリン性 アセチルコリン受容体を特異的にブロックすること で，コリン作動性ニューロンの神経伝達を阻害する 作用を持つ。

\section{$2.1 \mathrm{~F}$ | スケジュールでの結果}

Boren \& Navarro（1959）は，水を強化子とし， F R 26と F I 240 s が直列に配置され, それぞれのス ケジュールが別の信号刺激によって信号される多元 スケジュールで時間弁別を形成させた。その後アト ロピン投与では $2 \mathrm{mg} / \mathrm{kg}$ 以上で, スコポラミン投与で 
は0. $2 \mathrm{mg} / \mathrm{kg}$ 以上でスキャロップパターンが消失する ことを見いだした。Mckim (1974)もF I 120あるい は $240 \mathrm{~s}$ で時間弁別を形成させた後にスコポラミン $0.2 \mathrm{mg}$ $\mathrm{kg}$ から $3.2 \mathrm{mg} / \mathrm{kg}$ を投与し，スキャロップパターンが 消失し，C I が減少すると報告した。また，そのよ らな効果は投与量が多くなるにつれて大きくなった。 Charney \& Reynolds（1965）の研究は例外的に, F I 60 s での訓練開始当初から毎回投与を行った例 である。個体ごとに常にセッション開始前あるいは 終了後に, スコポラミン $0.6 \mathrm{mg} / \mathrm{kg}$ を119セッションに わたって投与した。その結果, セッション開始前に 投与を受けたラットは, 終了後に投与を受けたラッ トよりも, 要求時間に向かっての反応率の上昇が緩 やかであった。

\subsection{R Lスケジュールでの結果}

Kelsey \& Grossman（1975）は，D R L 30 s を用 いた。約 $30 \mathrm{~cm} の$ 走路の両端に設置されたオペラント 箱の一方でレバーに反応寸ると強化が与えられた。 次の強化を得るためには, 前の反応から $30 \mathrm{~s}$ 経過以 後に他方のオペラント箱のレバーに反応せねばなら なかった。行動が安定した後, スコポラミン0.1ある いは $0.5 \mathrm{mg} / \mathrm{kg}$ を皮下投与した結果，両方の投与量で 平均反応数が増加し, 強化数が減少した。この結果 は，スコポラミン投与によって反応の抑制が解除さ れ，失敗反応による情動的混乱を抑制できなかった ことによって生じたと解釈された。Ellen, Aitken, Sims, \& Stahl (1975) も, D R L 20s を用いた。行 動が安定した後に 4 日に 1 回の割合で 1 から $12 \mathrm{mg} / \mathrm{kg}$ までのアトロピンを投与した場合には，用量依存的 に短い I R Tを持つ反応が増加し, $12 \mathrm{mg} / \mathrm{kg}$ では I R $\mathrm{T}$ の度数分布が平坦化した。一方, 訓練当初からア トロピン $6 \mathrm{mg} / \mathrm{kg}$ を 15 日間毎回投与した場合には, 反 応数や強化獲得数は統制群と変わらなかった。Meyer, Severson, \& Thompson（1976）はDR L $15 \mathrm{~s}$ を用 い, スコポラミン, メチルスコポラミンおよび生理 食塩水を交替で各 3 回ずつ投与した。スコポラミン $0.5 \mathrm{mg} / \mathrm{kg}$ によって反応数が増加し, 反応数あたりの 強化獲得数が減少した。この結果は, 行動の抑制が 解除されたために生じたと解釈された。以上のよう に, D R L は反応抑制課題としての性質が強いこと から，このスケジュールを用いた研究では，抗コリ ン薬によって行動の抑制が解除され, 時間弁別行動 が障害されると解勫されることが多かった（この点 については, 和田・岩本 (1985) も指摘している)。 しかしSoffié \& Lejeune（1992）は，レバーAに対 する反応から 5 秒間の無反応の後に生じたレバーB への反応が強化されるという，2レバーのD R Lを 用いることで, 反応抑制の障害が起こっていても,
その効果を無視できると主張した。その根拠は, 食 事制限の長さを操作することによって活動性が変化 しても，A-Bの順序でのレバー反応の間隔は影響 を受けず， B-Aの順序のレバー反応（次の強化獲 得に必要な $\mathrm{A}-\mathrm{B}$ という反応系列への移行）の間隔 だけが変化するという Mechner \& Guevrekian(1962) の報告である。すなわち， A-B の順序の I R T 分 布は, 行動の抑制が解除され, 行動全般の頻度が増 加しても変化しないので, 行動抑制が解除されたと 考えられる事態であっても時間評価の指標として妥 当であると論じている。行動が安定した後, スコポ ラミン 0.15 あいは $0.5 \mathrm{mg} / \mathrm{kg}$ を投与すると， $0.5 \mathrm{mg} /$ $\mathrm{kg}$ 投与群では投与前後と比較して I R T 分布が平坦 化し，その中央值が小さな值に変化した。

\section{3 間隔二等分課題による結果}

Shurtleff, Raslear, Genovese, \& Simmons (1991) は, 短い刺激を $0.5 \mathrm{~s}$, 長い刺激を $5 \mathrm{~s}$ とする間隔二 等分課題を用いた。行動が安定した後, $0.075 か ら 0.422 \mathrm{mg} /$ $\mathrm{kg}$ のスコポラミンをそれぞれ 1 回だけ投与すると， $0.1 \mathrm{mg} / \mathrm{kg}$ 以上の量では二等分点と D L が小さくなっ た。ところで, Church et al. (1976) やSugita (1986)

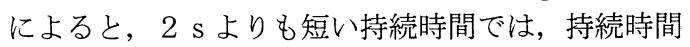
が短いほどウェーバー比が急激に増大し, $2 \mathrm{~s}$ 以降 ではほぼ一定となる。このことは，2 $\mathrm{s} よ り$ 短い持 続時間とそれよりも長い持続時間とが異なったシス テムによって測時されている可能性があることを示 唆している。したがって, この結果の解釈にあたっ ては, 同一の刺激系列にそれらの刺激を混在させる ことが適切であるか否かを考慮する必要があるだろ う。

以上のように, 媒介過程を想定していない研究で は, 抗コリン薬の単回性投与によって時間弁別の指 標の值が変化することが明らかになってきた。それ らの結果では反応数の増大も同時に観察されたこと から, 反応抑制機能が障害されるために時間弁別の 指標の值が変化すると解釈されることが多かった。 しかし, 反応抑制の障害と知覚レベルでの時間弁別 の障害とが独立な過程でありながら同時に生じた可 能性もある。したがって, それらの研究結果におけ る時間弁別行動の障害が, 反応抑制が障害されたた めに生じたのか, 知覚レベルでの時間の弁別が障害 されたために生じたのか, その両者が同時に生じた ために起こったのかは明らかではない。また, 単回 性投与に比心゙, 毎回投与では抗コリン薬の効果が見 られないか (Ellen et al., 1975)，見られたとしても わずかであった (Charney \& Reynolds, 1965)。

ところで, 以上のような結果は, 媒介過程につい てのモデルとの関係で論じられることはほとんどな 
かった（ただしSoffié \& Lejeune（1992）が考察で 触れている)。当時, ヒトの測時研究においてはすで に構成概念としての内的時計 (internal clock) を含 む媒介過程を仮定したモデルが提出されていたが (Creelman, 1962; Treisman, 1963), それらは動物 の測時を扱ったデータには適用されなかった。その 原因として, 強化スケジュールが元来, 行動分析的 研究で用いられてきたことから, 媒介過程による説 明を排除したモデルが構筑されてきたためであると の指摘がある（山田・和田・岩本, 1988)。また, 抗 コリン薬の効果を検討した研究でも，抗コリン薬が 反応抑制に関与するか否かが主な興味の対象であっ た場合が多かったのかもしれない。本節に引用した 研究の多くが行われた当時は, Carlton(1963)によっ て，抗コリン薬の投与がレバー押し反応の抑制機能 を障害するという報告がなされ, ACh系と反応抑制 機能との関係が注目されていた。例えば，他の強化 スケジュールである F R (Plotnik, Mollenauer, \& Milberg, 1976)やV I (Gonzalez \& Altshuler, 1979) での行動に対する抗コリン薬の効果について検討し た研究もあり,それらはいずれもCarltonの反応抑制 障害の説を検証したものであった。媒介過程を想定 していなかった研究は, 測時行動そのものに焦点を 当てたというよりはむしろ, 基本的な強化スケジュー ルでの行動一般に与える抗コリン薬の効果について, 探索的に検討することに重点を置いていたのかもし れない。

\section{3. 媒介過程についてのモデル}

1980年代前半以降方ら, 時間弁別行動を, 媒介過 程によって説明しようとするモデルが提出され, 損 傷や薬物投与などの効果をそれに基一、、解釈しよ うとする研究があらわれてきた。その代表が，近年 の大部分の時間弁別行動研究がその影響下にある

(Lejeune, Ferrara, Simons, \& Wearden, 1997 ; Machado,1997) といわれる“情報処理モデル”(Church, Meck, \& Gibbon, 1994 ; Gibbon, 1991 ; Meck, Church, \& Olton, 1984などを参照) と“測時につい ての行動的モデル (behavioral theory of timing ; B e T)" (Killeen \& Fetterman, 1988, 1991) であ る。ここでは, ピークインターバルでの動物の行動 パターンの分析によって B e Tよりも有効であるこ とが示され(詳細な分析についてはChurch, et al.(1994) とGibbon \& Church (1990，1992）を参照), 薬物 の効果を解勫する際に多くの研究で引用されてきた 情報処理モデルをごく簡単に紹介する。なお，それ 以前の記述的・説明的モデルについては, 山田ら (1988) の総説がある。 情報処理モデルは，スカラー測時理論（scalar expectancy theory； S E T) と呼ばれることもある が, S E Tは本来, 行動の記述モデルであるGibbon (1977)のscalar expectancy theoryの略語であるの で, Gibbon (1977) のscalar expectancy theoryを S E T と呼び, S E Tから導かれた認知モデルを“情 報処理モデル”と呼ぶことにする。Figure 1 に, 情 報処理モデルの概略を示す。情報処理モデルでは, 時間弁別行動が, 時計部(pacemaker/accumulator) ・ 参照記憶部（reference memory） • 反応決定部 (decision) とい5 3 つの部分からなる測時システム によって実現されると仮定している (Church et al. (1994), Gibbon (1991), Meck, et al. (1984) な どを参照)。時計部のペースメーカーは, 一定のペー スで一時貯蔵庫（accumulator）にパルスを送る。 一時貯蔵庫は送られてきたパルスを貯蔵する。ある 時点での反応が強化されると, 一時貯蔵庫に累積し ていたパルス值が参照記憶部に転送される。それ以 後の試行では, 参照記憶部に貯蔵されたパルス值と, 時間経過にともなって常に更新される一時貯蔵庫に 貯蔵されたパルス值とが反応決定部によって比較さ れる。比較された值が十分に接近していれば，反応 が生じる。

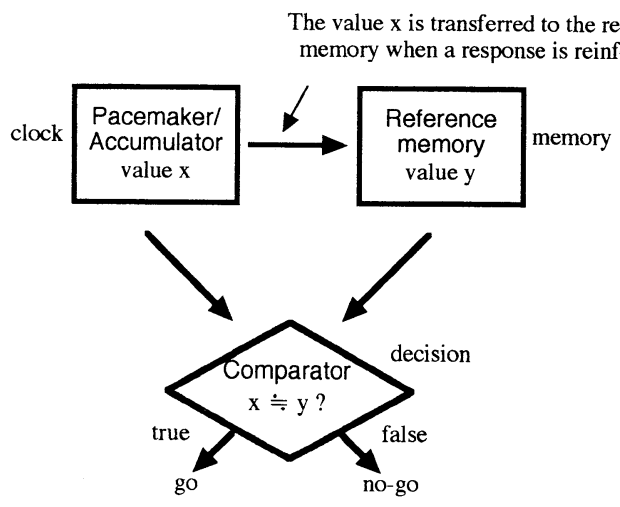

Figure 1. A sketch of the information processing model $^{3}$. Modified from Gibbon (1991).

\section{4. 情報処理モデルに基づいた研究}

情報処理モデルの登場によって, ACh系の操作が 媒介過程の変化をもたらし, 時閒弁別行動の変化と

3 情報処理モデルの細部は研究によって異なっている。 ここでは, 3 つ構成要素である, 時計部( clock)・記 憶部(memory) ・ 反応決定部(decision)を単純にまと めたモデルから改変した。またMeck (1996) では, accumulatorはintegratorと改訂されているが, 基本 的な機能はaccumulatorと同じであると思われる。 
して観察されるとする研究があらわれてきた。以下 に，それらの研究について概観する。Meck（1983） は, 標準刺激が $2 \mathrm{~s}$ と $8 \mathrm{~s}$ である間隔二等分課題を 用いて, 訓練開始当初から腹腔内一毎回投与するア トロピンの効果を検討した。その結果, $0.05 \mathrm{mg} / \mathrm{kg}$ の 投与量で，二等分点が統制条件よりも大きな值にな ることを示した。またMeck \& Church (1987 a ) は, P I 課題による訓練の開始時点からアトロピン $(0.05$, $0.15,0.45 \mathrm{mg} / \mathrm{kg})$ を毎回投与すると,訓練にともなっ て, 時間評価の測度であるピークタイムが用量依存 的に大きな值になることを示した。また，Meck \& Angell (1992) は, P I での行動が安定した後, 抗 コリン作用を持つピリチアミン（pyrithiamine） 4 $\mathrm{mg} / \mathrm{kg}$ を各セッション前に投与して訓練を続行した。 その結果，投与直後のセッションでは投与の効果は 見られなかったが，訓練を続けることによってピー クタイムがより大きな值になった。一方 ACh系の六 進は, 逆の効果をもたらす。Meck \& Church (1987 b ）は，ピークタイムでの時間弁別訓練の 20 分前に コリンの前駆物質であるレシチンを多く含んだ飼料 を与えたラットは，サッカリンを多く含んだ飼料を 与えたラットと比較して,訓練を重ねるにつれてピー クタイムが小さな值になると報告した。

以上のように, 情報処理モデルに基づいた研究で は，ACh系を毎回操作することよって時間評価の指 標の值に変化が見られた。Meck（1996）は，このよ うなピークタイムの経時的変化パターンを “記憶パ ターン”と呼び，その生起過程を次のように説明し ている (Church, Broadbent, \& Gibbon, 1992 ; Meck, 1996 ; Meck \& Angell, 1992)。抗コリン薬は 一時貯蔵庫に蓄えられた時間值が記憶部一転送され る “記憶貯蔵（memory-storage）”の過程に作用し， “記憶貯蔵スピード (memory-storage! seed)” 低下させることで，時間值を通常よりも大きな值と して記憶部に転送させるように働く。この初期の段 階では以前のベースライン期間中に記憶部に貯蔵さ れた時間值の方が優勢であり，それに基づいて反応 決定が行われるので, 時間評価の指標の值は変化し ない。しかし薬物の投与を継続することで, “記憶貯 蔵スピード”の低下が持続し, 参照記憶での時閒值 が正常よりも大きな值となるという状態が続けば, 記憶部では正常よりも大きな值が優勢になり，それ に基づいて反応決定が行われるようになるので，時 間評価の指標の值が大きくなる ${ }^{4}$ 。投与を中止した場 合には，その逆の過程を経るため，中止直後には中 止前の值が維持されるが，徐々にベースライン期間

$4 \mathrm{ACh}$ 系の機能え進は, “記憶貯蔵スピード”を速くさ せ，参照記憶での時間值が小さくなるという。
中の値にまで回復する。

\section{5．媒介過程を想定した研究とそうでな い研究との相違点}

Table 1 に, 以上の研究の概略を示した。以上のこ とから，媒介過程を想定した研究とそうでない研究 との間には，次のような違いがあることがわかる。 第 1 に，媒介過程を想定しない研究で何らかの薬物 投与の効果が現れたのは，主に単回性の投与を行っ た研究であったが，媒介過程を想定した研究では， 単回性の投与では効果が現れなかったという点であ る。すなわち，薬物投与下での訓練回数が異なって いた。第 2 に, 媒介過程を想定しない研究で用いら れた薬物・投与量では, 中枢神経の活動や行動を変 化させる程度が比較的強いことが推察されるという ことである。ここで, 代表的な抗コリン薬であるス コポラミンとアトロピンとでは，中枢神経の活動や 行動に与える効果の強さに大きな違いがあることに 注意する必要がある（mgベースで同量のスコポラミ ンとアトロピンを投与した場合，スコポラミンの方 が脳波に与える影響では約10倍以上（Vanderwolf, 1988), 強化が得られないにも関わらず生じる固執的 なレバー押し反応の誘発効果では約20倍 (Carlton, 1963), 水迷路での逃避行動の潜時を延長させる効果 では約25倍（Vanderwolf, 1991）強いとの報告があ る)。そして, 媒介過程を想定しない研究での用量は, スコポラミンで $0.1-3.2 \mathrm{mg} / \mathrm{kg}$, アトロピンでは 1 $12 \mathrm{mg} / \mathrm{kg}$ の範囲である。一方, 媒介過程を想定し, ス コポラミンを投与した研究は見あたらないが, $0.05 \mathrm{mg} /$ $\mathrm{kg}$ のアトロピンでもピークタイムに変化が見られて いる。この投与量は大変少なく, アトロピンは極端 に弱い作用しか持たないと考えられるにもかかわら ず，時間評価の指標に対する効果が見られたことに なる。

\section{6. 我々の実験}

我々（畑・岡市，1999）は，媒介過程を想定した Meckらの研究の枠組みで, それを想定していない研 究の結果も説明できるのではないかと考えた。つま り, 抗コリン薬の投与によって生じる時間弁別行動 の変化についての異なる結果が，薬物投与下での訓 練回数之，薬物が持つ，中枢神経の活動や行動を変 化させる程度の違いの相互作用によって生じたのか もしれないと考えた。なぜならば, Meckらは中枢の 神経活動や行動を変化させる程度が比較的低いと考 えられる量の抗コリン薬物を用いて，薬物投与下で の訓練を複数回継続して行うことによって時間の過 
Table 1. Profiles of cited studies

\begin{tabular}{|c|c|c|c|}
\hline study & task & effective drug $(\mathrm{mg} / \mathrm{kg})$ & main effect \\
\hline Boren \& Navarro (1959) ${ }^{\mathrm{A}}$ & FI & $\begin{array}{l}\text { atropine } \geqq 2 \\
\text { scopolamine } \geqq 0.2\end{array}$ & scallop disappeared \\
\hline Charney \& Reynolds $(1965)^{\mathrm{A}, \mathrm{C}}$ & FI & scopolamine 0.6 & weak scallop \\
\hline $\operatorname{Mckim}(1974)^{\mathrm{A}}$ & FI & $0.2 \leqq$ scopolamine $\leqq 3.2$ & $\begin{array}{l}\text { scallop disappeared } \\
\text { CI ! }\end{array}$ \\
\hline Ellen et al. $(1975)^{\mathrm{A}}$ & DRL & $1 \leqq$ atropine $\leqq 12$ & $\begin{array}{l}\text { short IRT } \\
\text { IRT distribution flattened }\end{array}$ \\
\hline Ellen et al. $(1975)^{\mathrm{A}, \mathrm{C}}$ & DRL & atropine 6 & no effect \\
\hline Kelsey \& Grossman $(1975)^{\mathrm{A}}$ & $\begin{array}{c}\text { DRL } \\
\text { (2 levers) }\end{array}$ & $\begin{array}{l}\text { scopolamine }^{\mathrm{D}} \\
0.1,0.5\end{array}$ & $\begin{array}{l}\text { number of responses } 1 \\
\text { reinforcement } \mid\end{array}$ \\
\hline Meyer et al. $(1976)^{\mathrm{A}}$ & DRL & scopolamine 0.5 & $\begin{array}{l}\text { number of responses } \mid \\
\text { acquired reinforcement rate } \mid\end{array}$ \\
\hline Shurtleff et al. $(1991)^{\mathrm{A}}$ & bisection & scopolamine $\geqq 0.1$ & $\begin{array}{l}\text { bisection point } \\
\text { DL । }\end{array}$ \\
\hline Soffié \& Lejeune $(1992)^{\mathrm{A}}$ & $\begin{array}{c}\text { DRL } \\
\text { (2 levers) }\end{array}$ & scopolamine $\geqq 0.5$ & $\begin{array}{l}\text { IRT distribution flattened } \\
\text { median IRT }\end{array}$ \\
\hline $\operatorname{Meck}(1983)^{\mathrm{B}, \mathrm{C}}$ & bisection & atropine 0.05 & bisection point $\mid$ \\
\hline Meck \& Church $(1987 \mathrm{a})^{\mathrm{B}, \mathrm{C}}$ & $\begin{array}{l}\text { peak } \\
\text { interval }\end{array}$ & $\begin{array}{l}\text { atropine } \\
0.05,0.15,0.45\end{array}$ & $\begin{array}{l}\text { peak time } \uparrow \\
\text { (dose dependent) }\end{array}$ \\
\hline Meck \& Church $(1987 b)^{B, C}$ & $\begin{array}{c}\text { peak } \\
\text { interval }\end{array}$ & lecithin $^{E}$ & peak time ! \\
\hline Meck \& Angell $(1992)^{\mathrm{B}, \mathrm{C}}$ & $\begin{array}{c}\text { peak } \\
\text { interval }\end{array}$ & pyrithiamine $^{\mathrm{F}} 4$ & peak time 1 \\
\hline
\end{tabular}

Note. $\mathrm{A}=$ Cognitive processes were not considered $\mathrm{B}=$ Cognitive processes were considered $; \mathrm{C}=$ Drug were injected every time ; $\mathrm{D}=$ s. c. injection ; $\mathrm{E}=$ includes choline ; $\mathrm{F}=$ indirect $\mathrm{A}$ Ch antagonist ; 1 =increased ; $1=$ decreased.

小評価が生じ，単回性の訓練であれば過小評価は生 じないと報告した。一方，抗コリン薬の作用が比較 的強かった媒介過程を想定しない研究では, 単回性 投与によってF I スケジュールでのスキャロップパ ターンや反応抑制の障害などの効果があらわれたが, 毎回投与ではこのような効果はみられなかった。こ れらのことから, 神経活動や行動を変化させる程度
が強い場合には，急性投与では反応抑制の障害があ らわれるが，複数回の訓練によってその障害が緩や かになるであろらと考えた。一方, 神経活動や行動 を変化させる程度が弱い場合には, 反応抑制の障害 が生じないことに加えて, Meckらが仮定したメカニ ズムによって (第 4 節参照), 複数回の投与を行わな いと時間の過小評価も生じないと仮定した。そこで, 
薬物の作用の強弱に対応する量として, スコポラミ ン0.5あるいは $0.15 \mathrm{mg} / \mathrm{kg}$ を選択し，P I 手続きによ る時間弁別行動を獲得済みのラットに15日閒に渡っ て毎回投与し，訓練を継続した。その後投与を中断 し,さらに 9 日間訓練を継続した。そして, 以下の ような仮説を設定した。 $0.5 \mathrm{mg} / \mathrm{kg}$ 群では投与期間の 初期には反応抑制の障害があらわれ, 複数回の訓練 によってその障害が緩やかになる。一方, $0.15 \mathrm{mg} / \mathrm{kg}$ 群では，投与期間の初期には反応抑制の障害はあら われず，時間の過小評価も生じない。しかし，投与 下での複数回の訓練によって, 時間の過小評価が生 じてくる。

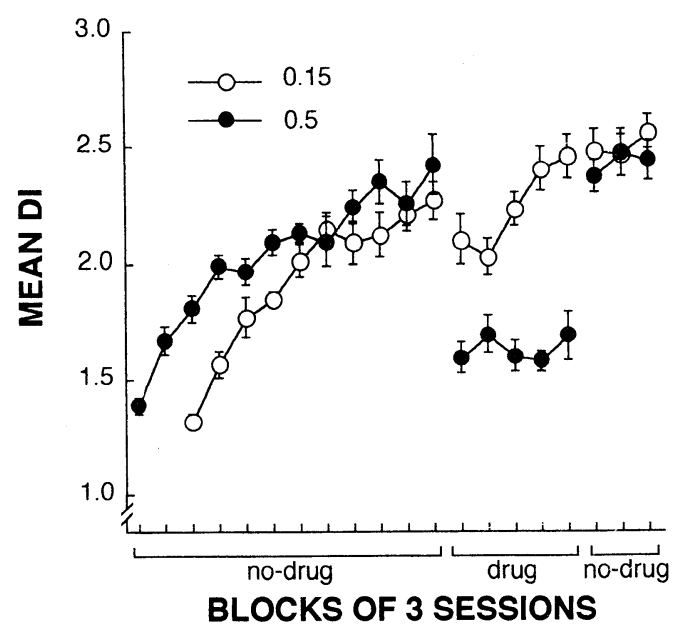

Figure 2. Mean DI values. In $0.5 \mathrm{mg} / \mathrm{kg}$ group, the DI value decreased through the drug phase. According to Meck \& Church (1987a), "DI=H/O, where $\mathrm{H}$ is the highest response rate in any 3 s period during the peak interval and $\mathrm{O}$ is the mean overall response rate during the peak interval. An index of 1.0 indicates no discrimination, and larger values indicate better discrimination."

その結果, $0.5 \mathrm{mg} / \mathrm{kg}$ 群では, 薬物投与の期間を通 じて反応率分布が平坦化し, Figure 2 に示すように, 時間弁別の指標であるD I 值が小さくなった。反応 率分布の平坦化は, 時間の弁別が困難になった場合 だけではなく，レバー反応が抑制できなかった場合 にも生じうる。通常のP I 手続きでは, 強化可能期 の開始時点付近をピークとする釣り鐘型の反応率分 布となるが, このような反応率分布は, 試行開始直 後付近と強化可能期の開始時点を過ぎた後での反応 が抑制されていくという過程を経て形成される。し たがって, レバー反応の抑制が障害されると, 通常 は抑制されていた反応が増加し, 反応率分布の平坦 化を生じさせるかもしれない。したがってこの結果
からだけでは，この反応率分布の平坦化が，反応抑 制が障害されたために生じたのか，知覚レベルで時 間の弁別が困難になったために生じたのか, その両 者が同時に生じたのかが不明である。そこでFigure 3 に示すように，I T I 中の反応率をみてみると, 薬物投与の初期のセッションでは高くなったが, 薬 物投与期間が進行するにつれて徐々に低下し，終盤 には投与前・あるいは投与後と変わらない水準にま で低くなった。このことは，投与期間の終盤では， 反応抑制の障害がほぼ消失したことを示している。 したがって，少なくとも薬物投与期間の終盤では, 時間弁別行動の悪化が, 反応抑制が障害されたこと によって二次的に生じたのではないことを示してお り, 知覚レベルでの時間弁別能力が障害されたこと を示唆していると考えられる。高用量で単回性の投 与を行った従来の研究では, 反応抑制の障害と知覚 レベルでの時閒弁別能力の障害とを分離することが 出来なかったが，毎回投与を行い，反応抑制の障害 が消失した段階での行動を見ることによって，時間 弁別能力の障害を分離することが出来た。一方, $0.15 \mathrm{mg} /$ $\mathrm{kg}$ 群では予測された時間の過小評価は生じず，反応 抑制の障害も生じなかった。

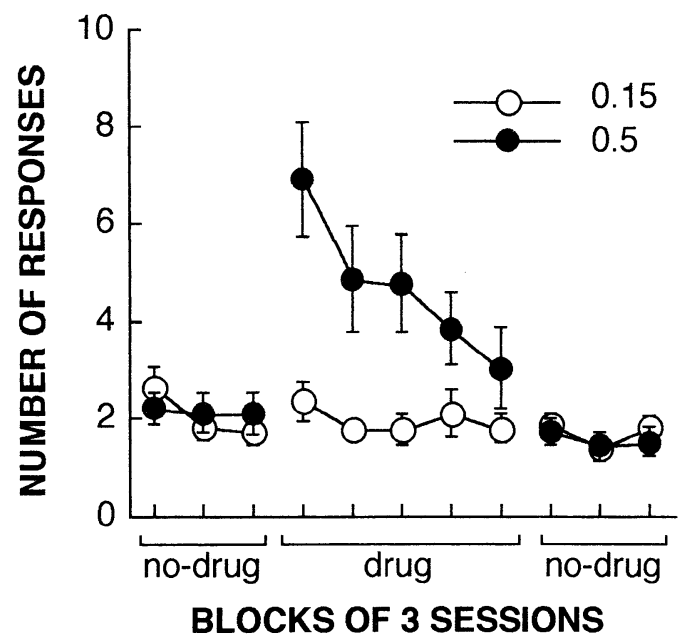

Figure 3. Mean number of responses per min during ITI. In $0.5 \mathrm{mg} / \mathrm{kg}$ group, the response rate during ITI recovered to the baseline level in the latter sessions of the drug phase.

\section{7. 時間弁別行動を情報処理モデルで 説明する際の問題点}

\section{1 情報処理モデル自体の問題点}

以下に, 情報処理モデルそのものの妥当性につい て検討する。はじめに, 情報処理モデルは, 測時行 動の特徴をよく説明できるモデルであることが示さ 
れてきている点, 時間弁別研究の発展を促した点, 薬物との対応関係についても言及している点におい て, 大変有力なモデルであることは疑いがない。し かし，以下のような問題点を指摘することできる。

まず，ペースメーカーからのパルスを貯蔵するとい ら一時貯蔵庫と, 作業記憶とが異なる概念であるの かどうかが曖昧である。例えば, Church \& Broadbent (1990) やCrystal, Church, \& Broadbent (1997) のモデルでは一時貯蔵庫と参照記憶とが作業記憶に よって仲介されているが, Church, et al. (1994) で は作業記憶はモデルに取り入れられていない。また, 時閒弁別には時閒についての参照記憶はそれほど重 要ではなく, むしろ直前の試行での経験によって制 御されるとする研究もある (Lejeune et al., 1997)。 さらに, 情報処理モデルでは説明できない現象が存 在することも明らかになってきている（例えば Broadbent, 1994 ; Kirkpatrick-Steger, Miller, Betti, \& Wasserman, 1996)。これらの知見をも統合 し，モデルを修正していく必要があるだろう。

\section{2 情報処理モデルと薬物との関係についての仮説 の問題点}

情報処理モデルと薬物との関係についての仮説の 妥当性についても, いくつかの疑問点がある。まず, Meckらのグループ以外の研究では, 抗コリン薬の投 与によって, 時間の過小評価が生じるという結果は 再現されず, 我々の研究では, 知覚レベルで時間弁 別能力が障害されることが示唆された。また, Meck （1996）は情報処理モデルと薬物との対応について 包括的に概観した研究であるが，その記述にはいく つかの曖昧な点が見つかる。例えば，“記憶パターン” と呼ばれるようなピークタイムの経時的変化は, “記 憶貯蔵スピード (memory-storage speed)”が変化 したことによって生じると述べていながら (p.237), その後, このような変化パターンが見られた結果が, “記憶貯蔵過程（memory-storage process）”が変 化したためではなく, “時間的処理のスピード（the rate of temporal processing)”が変化したために生 じたと述べている（p.238）。また, “時間的処理”と は具体的にどのような処理を意味するのかについて 説明されていない。さらに, “記憶貯蔵スピード”と いう概念や，なぜそれが変化することで参照記憶の 時間值が変化するのかが納得しがたい。以上のよう に, ACh系の機能抑制によって時間の過小評価が, 亢進によって過大評価が生じるといら結果や，それ は一時貯蔵庫から参照記憶への時間情報の転送機能 が影響をうけるために生じるとする解釈については 検討の余地があると思われる。

\section{8. 展望}

これまでの研究は, 抗コリン薬を全身性に投与し たものが多かった。しかし, Meck（1996）も指摘し ているように, ACh系のうちのどの部位がどのよう に時間弁別行動に関与しているのかを明らかにする ことが必要である。このためには, 脳内一の薬物の 微量投与などの手法が有効であろう。例えば, Blockland （1998）は，内在性のコリン作動性神経を多量に含 む線条体へのスコポラミンの微量投与は，FＩスケ ジュールでの反応パターンの時間評価の側面には影 響しないと報告している。また, 時間弁別行動を遂 行中の動物の中枢神経系でのACh系の活性を測定す るといらアプローチも有効であろう。最近, 主要な コリン作動性経路の構成要素である海馬系と前頭前 野とを損傷したラットにP I 手続きによる時間弁別 行動を行わせ, 前頭前野損傷によって時間弁別が障 害されるが，海馬損傷によっては障害されないとい う結果が報告された（Dietrich \& Allen，1998； Dietrich, Frederick, \& Allen, 1997 ; 畑・岡市, 1998)。 これを受けて現在我々は，海馬系と新皮質といら 2 つの主要なコリン作動性部位での細胞外ACh濃度を, 時間弁別行動を遂行中のラットから記録し, $\mathrm{ACh}$ 系 についても損傷研究の結果と同様な機能分離が存在 するか否かについて検討中である。

\section{引用 文 献}

Blokland, A. 1998 Involvement of striatal cholinergic receptors in reaction time and fixed-interval responding in rats. Brain Research Bulletin, 45, 21-25.

Boren, J. J., \& Navarro, A. P. 1959 The action of atropine, benactyzine, and scopolamine upon fixed-interval and fixed-ratio behavior. Journal of the Experimental Analysis of Behavior, 2, 107-115.

Broadbent, II. A. 1994 Periodic behavior in a random environment. Journal of Experimental Psychology: Animal Behavior Processes, 20, 156-175.

Carlton, P.L. 1963 Cholinergic mechanisms in the control of behavior by the brain. Psychological Review, 70, 19-39.

Catania, A. C. 1970 Reinforcement schedules and psychophysical judgments: A study of some temporal properties of behavior. In W. N. Schoenfeld (Ed.), The Theory of Reinforcement Schedules. New York: 
Appleton-Century-Crofts. Pp.1-42.

Charney, N. H., \& Reynolds, G. S. 1965 Development of behavioral compensation to the effects of scopolamine during fixed-interval reinforcement. Journal of the Experimental Analysis of Behavior, 8, 183-186.

Church, R. M. 1980 Short-term memory for time intervals. Learning and Motivation, 11, 208219.

Church, R. M., Getty, D. J., \& Lerner, N. D. 1976 Duration discrimination by rats. Journal of Experimental Psychology: Animal Behavior Processes, 2, 303-312.

Church, R. M., \& Broadbent, H. A. 1990 Alternative representations of time, number, and rate. Cognition, 37, 55-81.

Church, R. M., Broadbent, H. A., \& Gibbon, J. 1992 Biological and psychological description of an internal clock. In Gormezano, I., \& Wasserman, E. A. (Eds.), Learning and Memory: The behavioral and biological substrates. New Jersey: Lawrence Erlbaum Associates. Pp.105-128.

Church, R. M., Meck, W. H., \& Gibbon, J. 1994 Application of scalar timing theory to individual trials. Journal of Experimental Psychology: Animal Behavior Processes, 20, 135-155.

Creelman, C. D. 1962 Human discrimination of auditory duration. Journal of the Acoustical Society of America, 34, 582-593.

Crystal, J. D., Church, R. M., \& Broadbent, H. A. 1997 Systematic nonlinearities in the memory representation of time. Journal of Experimental Psychology: Animal Behavior Processes, 23, 267-282.

Dietrich, A., Frederick, D. L., \& Allen, J. D. 1997 The effects of total and subtotal prefrontal cortex lesions on the timing ability of the rat. Psychobiology, 25, 191-201.

Dietrich, A., \& Allen, J. D. 1998 Functional dissociation of the prefrontal cortex and the hippocampus in timing behavior. Behavioral Neuroscience, 112, 1043-1047.

Ellen, P., Aitken, W. C. Jr., Sims, T., \& Stahl, M. 1975 Cholinergic blockade, septal lesions, and DRL performance in the rat. Journal of Comparative and Physiological Psychology, 89, 409-420.
Fetterman, J. G., \& Killeen, P. R. 1995 Categorical scaling of time: Implications for clock-counter models. Journal of Experimental Psychology: Animal Behavior Processes, 21, 43-63.

Fry, W., Kelleher, R. T., \& Cook, L. 1960 A mathematical index of performance on fixed-interval schedules of reinforcement. Journal of the Experimental Analysis of Behavior, 3, 193-199.

Gibbon, J. 1977 Scalar expectancy theory and Weber's law in animal timing. Psychological Review, 84, 279-325.

Gibbon, J. 1991 Origins of scalar timing. Learning and Motivation, 22, 3-38.

Gibbon, J., \& Church., R. M. 1990 Representation of time. Cognition, 37, 23-54.

Gibbon, J., \& Church, R. M. 1992 Comparison of variance and covariance patterns in parallel and serial theories of timing. Journal of the Experimental Analysis of Behavior, 57, 393-406.

Gonzalez, L. P., \& Altshuler, H. L. 1979 Scopolamine effects on suppression of operant responding. Physiological Psychology, 7, 156-162.

畑 敏道・岡市広成 1998 ラットの時間弁別行動 に与える海馬采一脳弓損傷の効果 心理学研究, 69, 304-309.

畑敏道 - 岡市広成 1999 慢性scopolamine投与 によるラットの時間評価能力の悪化 動物心理 学研究, 49, 72 (抄録).

岩本隆茂 1981 時間弁別事態におけるオペラント 反応におよぼす強化と非強化の影響 心理学評 論, 24, 286-305.

Kelsey, J. E., \& Grossman, S. P. 1975 Influence of central cholinergic pathways on performance on free-operant avoidance and DRL schedules. Pharmacology Biochemistry \& Behavior, 3, 1043-1050.

Killeen, P. R., \& Fetterman, J. G. 1988 A behavioral theory of timing. Psychological Review, 95, 274-295.

Killeen, P. R. 1991 Behavior's time. The Psychology of Learning and Motivation, 27, 295-334.

Kirkpatrick-Steger, K., Miller, S. S., Betti, C. A., \& Wasserman, E. A. 1996 Cyclic responding by pigeons on the peak timing procedure. Journal of Experimental Psychology: Animal 
Behavior Processes, 22, 447-460.

Lejeune, H., Ferrare, A., \& Wearden, J. H. 1997

Adjusting to changes in the time of reinforcement: Peak-interval transitions in rats. Journal of Experimental Psychology: Animal Behavior Processes, 23, 211-231.

Machado, A. 1997 Learning the temporal dynamics of behavior. Psychological Review, 104, 241-265.

McKim, W. A. 1974 The effects of scopolamine and physostigmine on fixed-interval behaviour in the rat. Psychopharmacologia (Berl.), 39, 237-244.

Mechner, F., \& Guevrekian, L. 1962 Effects of deprivation upon counting and timing in rats. Journal of the Experimental Analysis of Behavior, 5, 463-466.

Meck, W. H. 1983 Selective adjustment of the speed of internal clock and memory processes. Journal of Experimental Psychology: Animal Behavior Processes, 9, 171201.

Meck, W. H., \& Church, R. M. 1987a Cholinergic modulation of the content of temporal memory. Behavioral Neuroscience, 101, 457-464.

Meck, W. H., \& Church, R. M. 1987b Nutrients that modify the speed of internal clock and memory storage processes. Behavioral Neuroscience, 101, 465-475.

Meck, W. H., Church, R. M., \& Olton, D. S. 1984 Hippocampus, time, and memory. Behavioral Neuroscience, 98, 3-22.

Meck, W. H., \& Angell, K. E. 1992 Repeated administration of pyrithiamine leads to a proportional increase in the remembered durations of events. Psychobiology, 20, 39-46.

Meck, W. H. 1996 Neuropharmacology of timing and time perception. Cognitive Brain Research, 3, 227-242.

Meyer, M. E., Severson, G. A., \& Thompson, R. W. 1976 Scopolamine, methylscopolamine, and response conditioned inhibition in rats. Physiological Psychology, 4, 43-44.
Plotnik, R., Mollenauer, S., \& Milberg, L. 1976 Scopolamine and food-reinforced behavior in the rat. Physiological Psychology, 4, 443-446.

Roberts, S. 1981 Isolation of an internal clock. Journal of Experimental Psychology: Animal Behavior Processes, 7, 242-268.

Schneider, B. A. 1969 A two-state analysis of fixed-interval responding in the pigeon. Journal of the Experimental Analysis of Behavior, 12, 677-687.

舌間 毅・岩崎庸男 1990 ラットの測時行動研究 の最近の動向 筑波大学心理学研究, 12, 75-83.

Shurtleff, D., Raslear, T. G., Genovese, R. F., \& Simmons, L. 1991 Perceptual bisection in rats: The effects of physostigmine, scopolamine and pirenzepine. Physiology \& Behavior, 51, 381-390.

Soffié, M., \& Lejeune, H. 1992 Cholinergic blockade and response timing in rats. Psychopharmacology, 106, 215-220.

Sugita, S. 1986 Duration discrimination of empty intervals in the rat. Japanese Psychological Research, 28, 176-185.

Treisman, M. 1963 Temporal discrimination and the indifference interval: Implications for a model of the "internal clock." Psychological Monographs: General and Applied, (No.576, Vol.77, No.13).

Vanderwolf, C. H. 1988 Cerebral activity and behavior: Control by central cholinergic and serotonergic system. International Review of Neurobiology, 30, 225-340.

Vanderwolf C. H. 1991 Anti-muscarinic drug effects in a swim-to-platform test: dose-response relations. Behavioral Brain Research, 44, 217-219.

和田博美・岩本隆茂 1985 ネズミの時間弁別行動 における生理心理学的機構 心理学評論, 28, 220-252.

山田弘司・和田博美・岩本隆茂 1988 モデル化に よる時間弁別機構へのアプローチ一動物実験か らの展望一 心理学評論, 31, 508-537. (1999. 9.28 受稿, 2000.1.20 受理) 